\title{
SELF-EXCITATION OF LOW-SPEED INDUCTOR GENERATOR
}

\author{
G. Diļev, B. Ose-Zạ̦ā \\ Institute of Physical Energetics, \\ 21 Aizkraukles Str., LV-1006, Riga, LATVIA \\ E. Jakobson \\ Riga Technical University, \\ 1 Kalıku Str., LV-1050, Riga, LATVIA
}

\begin{abstract}
The authors propose using the inductor generator with electromagnetic excitation in a wind-hydrogen independent power system for generation of the base load. They show that the remanent magnetic flux in such a generator is unable to create the electromotive force sufficient for its excitation from the cold start. This force and, therefore, power generation could be raised by introducing $\mathrm{NdFeB}$ permanent magnets in the slots of generator. Comparison of the conventional contactless generator and the generator with permanent magnets shows that the latter outperforms the former by such parameters as rotational speed range, efficiency and output, having at the same time smaller weight. The results of practical studies evidence that the inductor generator with a combined excitation system (electromagnetic excitation plus permanent magnets) can be a reliable power source in the independent wind-hydrogen systems.
\end{abstract}

Key words: wind-hydrogen, inductor generator, low-speed, permanent magnets.

\section{INTRODUCTION}

Nowadays, the renewable and $\mathrm{CO}_{2}$ emission free energy sources are becoming increasingly more employed in the autonomous power systems. The most advanced solutions involved relate to the parallel operation of several power sources, such as wind-diesel, wind-photovoltaic, wind-hydrogen, etc..

As concerns the use of wind energy, it is now developing in the direction of large and medium wind generators which are able to work in parallel with the grid or independently. In small-scale applications, the most common solution is a direct-drive synchronous generator with excitation from permanent magnets, which provides high efficiency and high installed power factor. However, its output voltage is unstable and depends on the rotational speed. The advantage of the electromagnetic excitation system is a stable output voltage control [1].

In this paper, we discuss the possibility to use a low-speed synchronous generator with contactless electromagnetic excitation for a wind-hydrogen independent power system. In the considered generator model all the windings are placed on the stator, and the rotor is tooth-like with no windings. The generator shown in Fig. 1 was designed at the Institute of Physical Energetics and manufactured at the Riga Electrical Machine factory. 


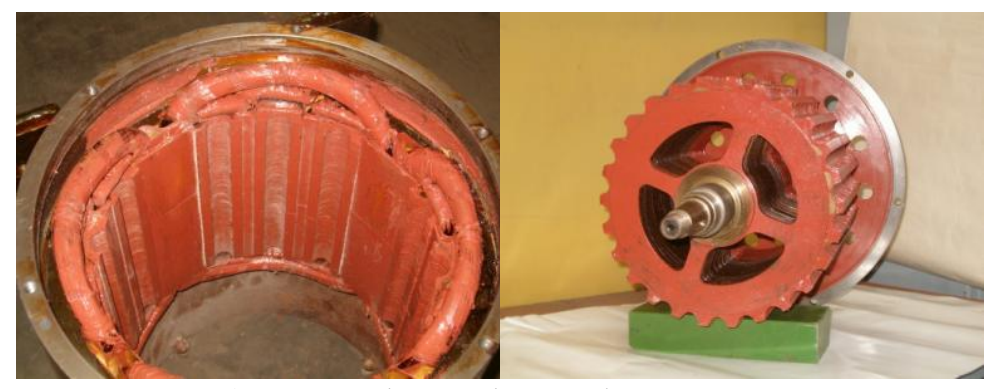

Fig. 1. Low-speed contactless synchronous generator.

\section{DESIGN OF THE GENERATOR}

Figure 2 shows a circuit diagram of the generator whose primary $(\mathrm{A}-\mathrm{X}, \mathrm{B}-$ $\mathrm{Y}, \mathrm{C}-\mathrm{Z})$ and excitation $(\mathrm{a}-\mathrm{x})$ windings are placed in the grooves of stator 1 . Accordingly, rotor 2 is tooth-like and has no windings. Each tooth 3 of rotor 2 corresponds to one pole pair. The total number of teeth can be rather big, which does not lead to enlargement of the stator winding coils, and, therefore, of the magnetizing current. The primary windings are situated in pole extensions 4 . Each pole extension between two slots can have up to five smaller teeth with pitch $t_{z p}$, which is equal to pitch $t_{z}$ of the rotor teeth [2,3].

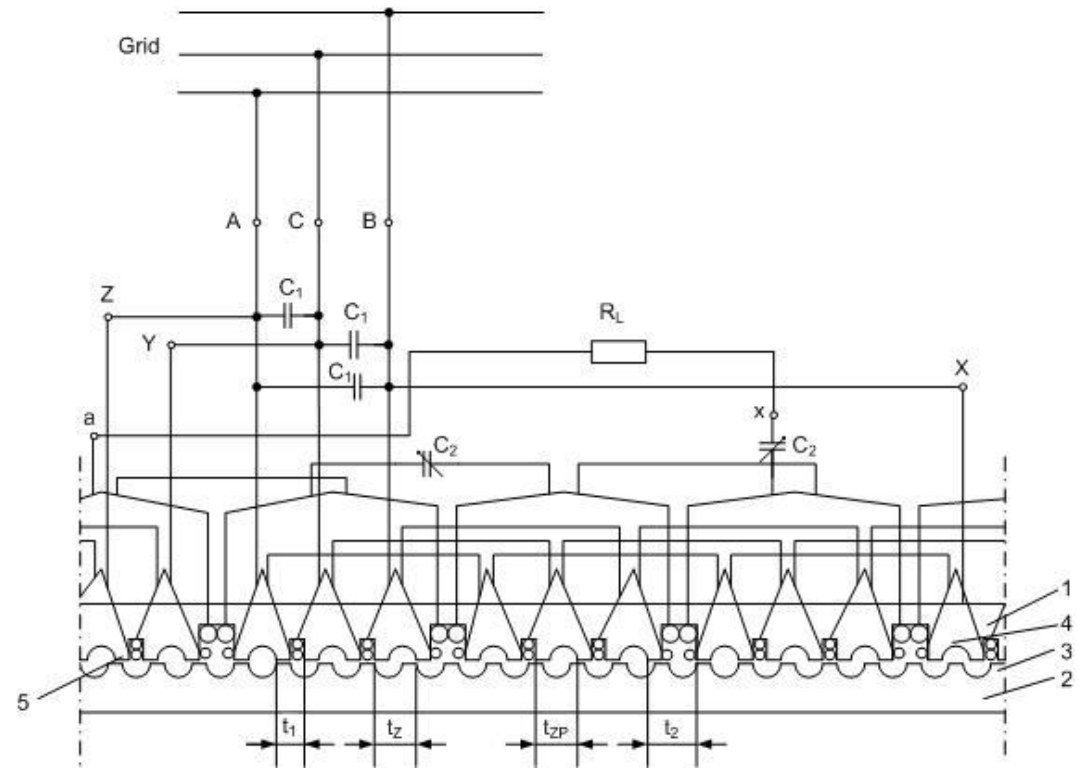

Fig. 2. Circuit diagram of the induction generator with primary $(\mathrm{A}-\mathrm{X}, \mathrm{B}-\mathrm{Y}, \mathrm{C}-\mathrm{Z})$ and secondary $(\mathrm{a}-\mathrm{x})$ windings on the stator. 1 - stator; 2 - rotor; 3 - rotor teeth; 4 - pole extension; 5 - teeth on the pole extension; $\mathrm{C}_{1}, \mathrm{C}_{2}$ - capacitors in the primary and secondary circuits; $\mathrm{R}_{\mathrm{L} 1}$ - controlled secondary load resistance; $t_{Z}, t_{Z P}, t_{1}, t_{2}-$ stator and rotor tooth pitches; $k_{1}-k_{2}-\mathrm{NC}$ contacts.

At rotation, the rotor teeth change their location with respect to the stator pole extension - from teeth to grooves; this, in turn, causes a periodical change in the magnetic conductivity from minimum to maximum. The conductivity of the $K$-th pole extension can be described by a Fourier's periodic function series as 


$$
\begin{aligned}
\lambda_{k} & =a_{0}+a_{1} \cos \left(Z_{R} \alpha-\varphi_{k}\right)+a_{2} \cos 2\left(Z_{R} \alpha-\varphi_{k}\right)+ \\
& +a_{3} \cos 3\left(Z_{R} \alpha-\varphi_{k}\right)+\cdots+a_{v} \cos v\left(Z_{R} \alpha-\varphi_{k}\right) .
\end{aligned}
$$

To avoid the total harmonics distortion (THD), the width of a stator's tooth is to be $t_{Z} / 3$, and the gap between the teeth should be calculated assuming the radius of $t_{Z} / 3$ [4]. Accordingly, Eq. (1) can be rewritten as

$$
\lambda_{k}=a_{0}+a_{1} \cos \left(Z_{R} \alpha-\phi_{k}\right),
$$

where $a_{0}$ is the constant magnetic conductivity of the pole extension;

$a_{1}$ is the amplitude of first harmonics of a pole extension's magnetic conductivity;

$Z_{R}$ is the number of rotor teeth (pole pairs);

$\varphi_{k}$ is the phase angle [5].

The periodic change in the magnetic conductivity causes a corresponding periodic change in the magnetic-flux linkage, which means variations in the power transferred to the grid and to the secondary load. According to the above mentioned and to Fig. 2, it is possible to obtain equations for the magnetic flux linkage as

$$
\begin{aligned}
& \Psi_{A}=w_{k 1}\left(\begin{array}{l}
\left(\lambda_{1}+\lambda_{7}\right)\left(w_{k 1} i_{A}+w_{k 2} i_{a}\right)+ \\
+\left(\lambda_{4}+\lambda_{10}\right)\left(w_{k 1} i_{A}-w_{k 2} i_{a}\right)
\end{array}\right)= \\
& =4 a_{0} w_{k 1}^{2} i_{A}+4 a_{1} w_{k 1} w_{k 2} i_{a} \cos \left(Z_{R} \alpha\right) \text {; } \\
& \Psi_{B}=w_{k 1}\left(\begin{array}{l}
\left(\lambda_{3}+\lambda_{9}\right)\left(w_{k 1} i_{B}+w_{k 2} i_{a}\right)+ \\
+\left(\lambda_{6}+\lambda_{12}\right)\left(w_{k 1} i_{B}-w_{k 2} i_{a}\right)
\end{array}\right)= \\
& =4 a_{0} w_{k 1}^{2} i_{B}+4 a_{1} w_{k 1} w_{k 2} i_{a} \cos \left(Z_{R} \alpha-120^{\circ}\right) \text {; } \\
& \Psi_{C}=w_{k 1}\left(\begin{array}{l}
\left(\lambda_{2}+\lambda_{8}\right)\left(w_{k 1} i_{C}+w_{k 2} i_{a}\right)+ \\
+\left(\lambda_{5}+\lambda_{11}\right)\left(w_{k 1} i_{C}-w_{k 2} i_{a}\right)
\end{array}\right)= \\
& =4 a_{0} w_{k 1}^{2} i_{C}+4 a_{1} w_{k 1} w_{k 2} i_{a} \cos \left(Z_{R} \alpha-240^{\circ}\right) \text {; } \\
& \Psi_{a}=w_{k 2}\left(\begin{array}{l}
\left(\sum_{k=i}^{12} \lambda_{k}\right) w_{k 2} i_{a}+\left(\lambda_{1}+\lambda_{7}-\lambda_{4} \lambda_{10}\right) w_{k 1} i_{A}+ \\
+\left(\lambda_{3}+\lambda_{9}-\lambda_{6}-\lambda_{12}\right) w_{k 1} i_{B}+\left(\lambda_{2}+\lambda_{8}-\lambda_{5}-\lambda_{11}\right) w_{k 1} i_{C}
\end{array}\right)= \\
& =12 a_{0} w_{k 2}^{2} i_{a}+4 a_{1} w_{k 1} w_{k 2} i_{A} \cos \left(Z_{R} \alpha\right)+ \\
& 4 a_{1} w_{k 1} w_{k 2} i_{B} \cos \left(Z_{R} \alpha-120^{\circ}\right)+4 a_{1} w_{k 1} w_{k 2} i_{C} \cos \left(Z_{R} \alpha-240^{\circ}\right) \text {. }
\end{aligned}
$$

Next, it is possible to calculate the equations for the EMF and currents:

$$
u_{A B}=i_{A} R_{A}+\frac{d \Psi_{A}}{d t}
$$




$$
\begin{aligned}
& u_{B C}=i_{B} R_{B}+\frac{d \Psi_{B}}{d t} ; \\
& u_{C A}=i_{C} R_{C}+\frac{d \Psi_{C}}{d t} ; \\
& i_{1 A}=i_{A}+i_{C 1 A}-i_{C}-i_{C 1 C} ; \\
& i_{1 B}=i_{B}+i_{C 1 B}-i_{A}-i_{C 1 A} ; \\
& i_{1 C}=i_{C}+i_{C 1 C}-i_{B}-i_{C 1 B} ; \\
& 0=i_{a}=\left(R_{2}+R_{z l}\right)=2 U_{C 2}+\frac{d \Psi_{a}}{d t},
\end{aligned}
$$

where $u_{A B}, u_{B C}, u_{C A}$ are the grid line voltages;

$i_{1 A}, i_{1 B}, i_{1 C} \quad$ are the grid currents;

$i_{A}, i_{B}, i_{C} \quad$ are the phase currents of the generator;

$i_{C 1 A}, i_{C 1 B}, i_{C 1 C}$ are the capacitor $\mathrm{C}_{1}$ currents;

$R_{1}, R_{2}$ are the active resistances of primary and secondary windings;

$R_{s l} \quad$ is the active resistance of the secondary load;

$U_{C 2} \quad$ is the voltage drop on capacitor $C_{1}$ [6].

With these equations it is possible to solve the most difficult tasks met in application of low-speed generators - e.g. to perform analysis of transient processes.

Our proposal is based on the idea that during the rotation the secondary winding generates the EMF proportional to slip $s=1-\frac{n Z_{R}}{60 f}$ (where $f$ is the primary current frequency). This generator can operate as synchronous with electromagnetic excitation. For this it is necessary to supply DC current to the secondary winding $(\mathrm{a}-\mathrm{x})$. In this case, capacitors $C_{2}$ and load resistance $R_{L}$ are eliminated from the circuit [7].

\section{PHYSICAL BASIS OF THE PRACTICAL STUDIES}

The wind-hydrogen based independent energy supply system is applicable in the rural regions isolated from the power grid. Its total power is $10 \mathrm{~kW}$, which is enough for the needs of small autonomous locations; the system provides the possibility to connect more consumers. In the basic solution a $5 \mathrm{~kW}$ wind generator is equipped with a low-speed generator connected through the voltage control device to a 540 VDC bus, from where a hydrogen production unit is supplied. The unit has a hydrogen storage tank. When wind is blowing and the electrical energy is produced while the consumer does not use it, this energy is used to produce hydrogen. The next in importance is a fuel cell supplied from the hydrogen tank and performing the opposite operation - the conversion of hydrogen to 540 VDC electrical energy. This latter works in the time when the wind turbine is not producing electrical energy. In this case the energy is supplied from the hydrogen tank. The consumer is connected through a converter and receives electric energy 
(3-phase 400 VAC) for the household needs. These modules are basic for such an autonomous system; it is also possible to add a solar panel or batteries and another power converter as well as accumulating or consuming units. If needed, a special converter would provide the possibility to connect such an autonomous system to the power grid.

In the basic case, the main energy supply unit is a $5 \mathrm{~kW}$ wind turbine. In this autonomous system the electric machine is employed as a synchronous generator with self-excitation. The use of such a machine is the best solution for an independent system in the absence of power grid.

The practical studies were carried out for a contactless inductor generator with electromagnetic excitation operating in the autonomous operation mode. Its output voltage was $400 \mathrm{VAC}$, while the operation conditions for the permanent magnet synchronous generator (PMSG) were set to keep the 566 VDC output. The criteria for comparison were: stable output voltage of $400 \mathrm{VAC}$ for the inductor generator and of $566 \mathrm{VDC}$ for the PMSG. The generated power curves are shown in Fig. 3. The power curve for the inductor generator is reduced for a constant excitation current and variable speed [8].

Comparison of the generators (Table 1) was done at the constant excitation current $I_{f}=21 \mathrm{~A}$.
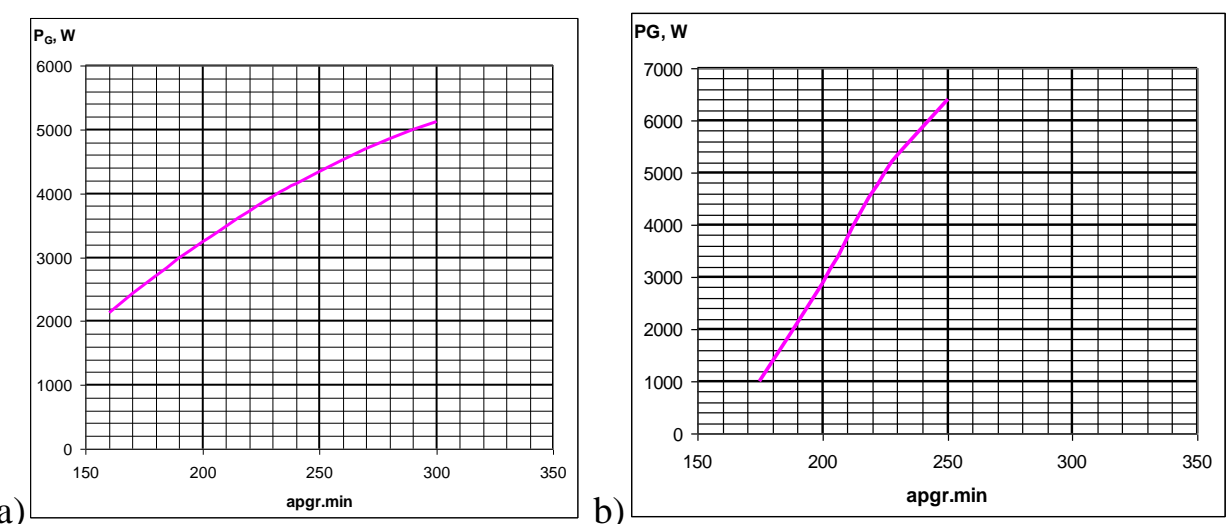

Fig. 3. Curves of power generated at different rotation speeds for $a$ ) inductor generator; $b$ ) PMSG.

Comparative parameters of inductor generator and PMSG

\begin{tabular}{|l|c|c|}
\hline \multicolumn{1}{|c|}{ Parameter } & Inductor generator & PMSG \\
\hline Rotation speed range, $\mathrm{min}^{-1}$ & $160-320$ & $175-250$ \\
\hline Efficiency factor & $0.60-0.71$ & $0.9-0.8$ \\
\hline $\begin{array}{l}\text { Maximum possible power at constant } \\
\text { output voltage, } \mathrm{kW}\end{array}$ & $2-5$ & $1-6.3$ \\
\hline Generator weight, $\mathrm{kg}$ & 250 & 140 \\
\hline
\end{tabular}

It is obvious that the PMSG has higher efficiency (taking into account the mass and efficiency factors), while the operation speed range of the inductor 
generator is wider because of the electromagnetic excitation, although it is easier to control its output voltage. The PMSG output voltage is only related to the load of generator and its rotational speed [9].

\section{REMANENT MAGNETISM OF THE INDUCTOR GENERATOR}

The remanent magnetism plays an important role in the requirements imposed on the synchronous generator with electromagnetic excitation to be used in the above described independent power system. However, the remanent magnetism of this type generator is insufficient to create voltage from the cold start (as shown in Fig. 4).

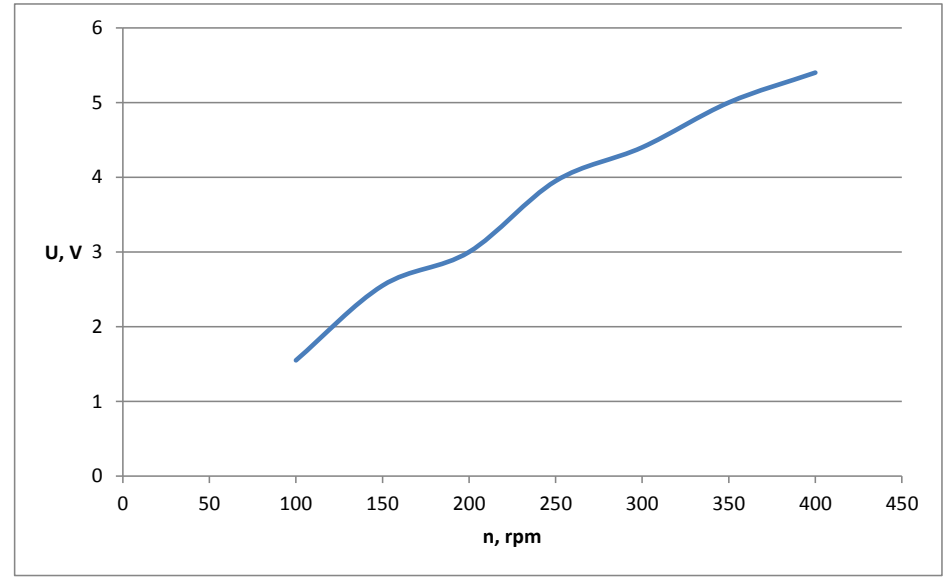

Fig. 4. Remanent electromotive force for the inductor generator.

The proposed solution to this problem is to introduce a thin layer of permanent magnets into the slots of excitation winding in order to increase the remanent EMF. The requirements for the permanent magnets were: $\mathrm{NdFeB}$ magnetic material, thickness $1 / 10$ ”, $H=900000 \mathrm{~A} / \mathrm{m}^{2}$. The results of magnetic field modelling are shown in Fig. 5.

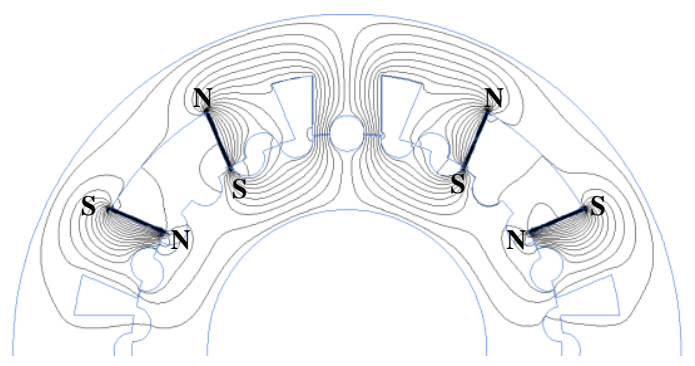

Fig. 5. The magnetic field modelled for the remanent magnetic flux $\Phi$ which generates emf in the primary winding.

The magnetic flux $\Phi$ through one stator pole extension (created by a pair of magnets placed in the slots of the excitation winding) equals to $0.003 \mathrm{~Wb}$. The corresponding EMF induced in the coils of a primary winding at the generator rotation frequency of 115 RPMs is shown in Fig. 6. 


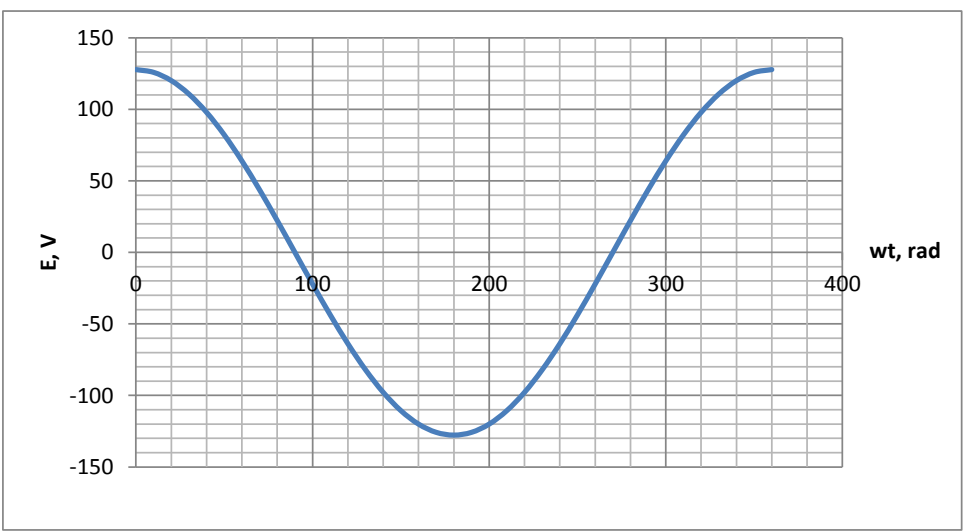

Fig. 6. Electromotive force induced in the primary winding by permanent magnets.

\section{CONCLUSIONS}

The practical studies on the inductor generator with electromagnetic excitation have shown that it can be applied as a wind generator in the proposed wind-hydrogen independent power system.

Since the remanent magnetic flux is insufficient to create electromotive force for excitation of the generator, $\mathrm{NdFeB}$ permanent magnets are placed in its slots to provide the power generation from the cold start.

The inductor generator with a combined excitation system (electromagnetic excitation plus permanent magnets) is shown to be a reliable power source in the independent wind-hydrogen systems.

\section{ACKNOWLEDGEMENT}

This article has been supported by the European Regional Development Fund within the project „Stand-alone electricity supply system based on wind energy and hydrogen", No. 2010/0188/2DP/2.1.1.1.0/10/APIA/VIAA/031.

\section{REFERENCES}

1. Ackerman, T. (2005). Wind Power in Power Systems. Stockholm: John Wiley \& Sons Ltd, $691 \mathrm{p}$.

2. Diḷevs, G., Levin, N., Pugachev, V., \& Ribickis, L. (2009). Divpusējās barošanas asinhronais generators (Publ. 2009.08.20) Patenti un preču zimes, (8), p.1103.

3. Левин, Н., \& Серебряков, А. (1976). Электропривод на базе двигателей со взаимно-неподвижными обмотками. Электрические машиы и приводы, Вып. 3, Рига.

4. Dilevs, G., Levin, N., \& Pugachev, V. (2007). Daudzpolu asinhronie vēja ǵeneratori. Latv. J. Phys. Tech. Sci., (5), 15-22.

5. Dilevs, G., \& Jakobsons, E. (2008). The power control of the multipole double fed induction wind generator. RTU Sci. Proceedings. Part 4: Power and electrical engineering, 23, Riga: RTU, $111-116$.

6. Pugachev, V., Levin, N., Ribickis, L., \& Manonov, M. (2003). A multipolar inductor generator of annular design for windmills. Energétika un elektrotehnika, 4(10), Riga: RTU Zinātniskie raksti, 10-15.

7. Волдек, А. (1974). Электрические машины. Москва: Энергия. 
8. Gieras, J. F., \& Wing, M. (2002). Permanent Magnet Motor Technology. Design and Application ( $2^{\text {nd }}$ ed-n, revised and expanded). London: UK BT Cellnet, 590 p.

9. Levins, N., Kamolinšs, E., \& Vītoliņa, S. (2011). Bezkontaktu Elektriskās Mašīnas. Rīga: RTU, 275 lpp.

\section{PAŠIEROSMES UZLABOŠANA LĒNGAITAS INDUKOTRĢENERATORAM}

G. Diḷ̂evs, B. Ose-Zaḷā, E. Jākobsons

Kops avilkums

Tiek piedāvāts izmantot induktorǵeneratoru autonomajā energoapgādes sistēmā, kas balstîta uz vēja energoiekārtas un ūdeņraža energoiekārtas paralēlo darbību, bāzes jaudas radīšanai. Publikācijā minēti tehniskie nosacījumi šādam ǵeneratoram. Izklāstītas praktiskās izpētes rezultāti un dotas rekomendācijas konstrukcijas uzlabošanai pašierosmes nodrošināšanai.

29.07.2012 